\title{
Bilateral renal cell carcinoma in a paediatric patient with tuberous sclerosis complex
}

\author{
Ana Teresa Gil, Ana Brett, Carolina Cordinhã, Clara Gomes
}

Pediatric Nephrology Unit, Pediatric Hospital Carmona da Mota, Hospital Center and University of Coimbra, Coimbra, Portugal

\section{Correspondence to} Dr Ana Teresa Gil, ateresagil@gmail.com
To cite: Gil AT, Brett $A$, Cordinhã C, et al. BMJ Case Rep Published online: [please include Day Month Year] doi:10.1136/bcr-2013010015

\section{SUMMARY}

Tuberous sclerosis complex (TSC) is a genetic neurocutaneous disorder characterised by seizures, mental retardation and hamartoma formation in multiple organs, mainly in the brain, skin, kidney, liver, lung and heart. Renal manifestations occur in about $60-80 \%$ of all patients with TSC and their rate increases with age. We report the case of a 17-year-old boy with tuberous sclerosis who presented with abdominal pain associated with kidney failure. Investigation revealed bilateral renal lesions, suggesting angiomyolipomas. On further workup, malignancy was suspected and the patient underwent bilateral partial nephrectomy with histological diagnosis of bilateral renal cell carcinoma. This is a rare complication of TSC, particularly in a paediatric setting. Adequate surveillance of kidney disorders in patients with TSC is warranted, to guarantee an early diagnosis and treatment.

\section{BACKGROUND}

Tuberous sclerosis complex (TSC), an autosomal dominant disease, is a relatively frequent disorder, seen in approximately 1:6000 people worldwide. ${ }^{1}$ Affected patients are at risk of development of tumoral lesions in a number of organs, namely brain, skin, kidney, liver, lung and heart. ${ }^{2}$

TSC is caused by mutations in either one of the two tumour suppressor genes: the TSC1 gene (on chromosome 9q34) or the TSC2 gene (on chromosome $16 \mathrm{p} 13) .{ }^{3}{ }^{4}$ Both mutations impact the same organ systems, but it is believed that TSC2 mutations lead to a more severe outcome, including more acute renal involvement. ${ }^{5} 6$

A set of diagnostic criteria, established at the Tuberous Sclerosis Complex Consensus Conference in 1998, are used to diagnose TSC. ${ }^{7}$ The phenotype in TSC is highly variable, even in patients with identical mutations. The classic triad (Vogt's triad) is characterised by seizures, mental retardation and facial angiofibromas. However, less than $40 \%$ of patients have all three features and some patients may have none. ${ }^{8}$ Likewise, the diagnosis may not become evident until adulthood since clinical symptoms may appear gradually. ${ }^{9}$

Although TSC most often presents with neurological symptoms, renal involvement is common, occurring in 50-80\% of patients and increases with age. ${ }^{5} 10$ The most frequent renal lesions are angiomyolipomas (AMLs) and renal cysts, both of which may lead to chronic kidney disease (CKD). ${ }^{8} \quad 10$ Renal cell carcinoma (RCC) is a rare complication of TSC in children, ${ }^{11}$ more commonly reported in adults.
The case of an adolescent with TSC and malignant renal disease is presented, with the aim of increasing awareness to this association in a paediatric setting.

\section{CASE PRESENTATION}

A 17-year-old boy, diagnosed at the age of seven with TSC, was admitted to his local hospital in March 2012 with right lumbar pain.

The pain had started $24 \mathrm{~h}$ prior to admission, after a coughing bout and was described as a continuous pain that radiated to his right thigh. $\mathrm{He}$ had a 5 day history of upper respiratory tract infection, but with no fever, gastrointestinal or genitourinary symptoms.

Regarding his medical history, the patient was diagnosed with TSC at 7 years of age after he presented with new onset of seizures and was recognised to have hypopigmented macules. $\mathrm{He}$ is chronically medicated with sodium valproate.

On physical examination, he was found pale, had trouble walking and had symptoms of pain when pressure was applied to his right abdominal quadrant, which was tender on palpation but without rebound tenderness or rigidity. Murphy's punch sign was negative bilaterally.

Laboratory investigation showed: haemoglobin $10.4 \mathrm{~g} / \mathrm{dL}$, leucocytes $4900 / \mu \mathrm{L}, \mathrm{C}$ reactive protein (CRP) $9.3 \mathrm{mg} / \mathrm{dL}$, serum creatine $219 \mu \mathrm{mol} / \mathrm{L}$, urea $12.9 \mathrm{mmol} / \mathrm{L}$, with normal electrolytes, suggesting kidney failure. The abdominal ultrasound showed a heterogeneous mass with $8.1 \times 7.2 \mathrm{~cm}$ on the right kidney. The patient was transferred to a referral centre for follow-up.

In the tertiary centre he repeated blood tests, which confirmed anaemia $(9.6 \mathrm{~g} / \mathrm{dL})$ and kidney failure and showed an elevated erythrocyte sedimentation rate $(112 \mathrm{~mm} / \mathrm{h})$ and rising CRP $(15.3 \mathrm{mg} / \mathrm{dL}$ ). The autoimmune panel (antinuclear antibody, extractable nuclear antigen, antineutrophil cytoplasmic antibody and complement) was normal. Urinalysis showed nephrotic proteinuria (urine protein/creatine ratio: $209 \mathrm{mg} / \mathrm{mmol}$ ). He was initially prescribed with intravenous antibiotics (ceftriaxone and flucloxacillin), as a renal abscess was suspected. High blood pressure was noted and he was started on oral nifedipine and atenolol.

A new renal ultrasound showed bilateral diffuse hyper-reflectivity and bilateral mass lesions $(10 \mathrm{~cm}$ of diameter on the right kidney and $2.1 \mathrm{~cm}$ on the left kidney), which were predominantly solid, with significant inner abnormal vasculature. The mass on the left kidney had two foci of calcification. These aspects suggested AML 
although malignancy could not be excluded as both lesions were highly vascularised.

With treatment, he maintained a low glomerular filtration rate $\left(33 \mathrm{~mL} / \mathrm{min} / 1.73 \mathrm{~m}^{2}\right)$, which, when associated with anaemia and his kidney pattern on ultrasound, confirmed the diagnosis of chronic kidney failure. He was started on calcitriol, calcium carbonate and darbepoietin.

An abdominal CT scan without contrast showed possible bilateral AML with internal haemorrhage, although the possibility of RCC could not be excluded. An MRI confirmed these findings, suggesting a possible malignant aetiology for the lesion in the left kidney. Therefore, a biopsy of the lesion in the left kidney was performed, which showed a histological appearance of RCC, clear cell type, Fuhrman grade 1.

\section{TREATMENT}

Accordingly, he was transferred to the adult Urology Department and had a bilateral partial nephrectomy. A nodule was excised from the left kidney with $1.8 \times 1.5 \times 1.5 \mathrm{~cm}$, with well-defined limits and a free surgical margin. The histological appearance of this nodule confirmed RCC, clear cell type, Fuhrman grade 3 . From the right kidney a mass with $6.5 \times 5 \times 5 \mathrm{~cm}$ was removed, which on macroscopic appearance showed cystic and haemorraghic areas, close to the surgical margin $(1 \mathrm{~mm})$ without invasion of the renal capsule. Microscopically the lesion showed eosinophilic cytoplasm cells in the core and clear cells in the peripheral areas, and was histologically classified as a chromophobe RCC (immunohistochemical phenotype: positive epithelial membrane antigen (EMA), with rare cells reactive to HMB-45 and cytokeratin 7). The remaining renal parenchyma had typical abnormalities of TSC.

According to the TNM staging classification system the patient had a T1B N0 M0 RCC.

\section{OUTCOME AND FOLLOW-UP}

After surgery, the patient remained clinically stable, without any newly identified lesions, and with a glomerular filtration rate of $26 \mathrm{~mL} / \mathrm{min} / 1.73 \mathrm{~m}^{2}$, corresponding to CKD stage 4 .

\section{DISCUSSION}

Renal manifestations are a common finding in TSC and play a significant role in disease burden, as they frequently progress to CKD and are the most common cause of death in these patients. ${ }^{12}$ An adequate surveillance is essential for early detection of renal lesions and effective management, as these are rarely symptomatic in initial stages of TSC. ${ }^{5}$

Patients with TSC should remain under medical surveillance and should be periodically examined, to assess for development and progression of renal lesions. The TSC Consensus Conference recommends ultrasound screening of the kidneys every 1-3 years in older children with TSC. ${ }^{7}$ This case report illustrates the need for early and frequent renal imaging in paediatric patients with TSC.

AMLs, the most frequent renal tumours in TSC, are mesenchymal hamartomas composed (in varying proportions) of smooth muscle cells, adipocytes and abnormal blood vessels. ${ }^{5}$ In patients with TSC they are usually cortical, multifocal and bilateral. ${ }^{9}$ These lesions have a high risk of intralesion haemorrhage, which can cause discomfort or pain and can invade adjacent normal renal parenchyma, consequently compromising renal function. ${ }^{5}$ AMLs usually appear during childhood and adolescence and then stabilise throughout adulthood. ${ }^{8}$ In this case report, AML was initially considered the most likely aetiology for the kidney lesions, as these showed significant inner abnormal vasculature.

The actual incidence of renal malignancies in patients with TSC is unknown. The estimated incidence of RCC varies between $2.2 \%$ and $5 \%,{ }^{5} 813$ similar to that of the general population, ${ }^{2}$ with a higher frequency in women. ${ }^{14}{ }^{15}$ However, the median age of diagnosis of RCC in TSC is reported as 28 years, ${ }^{15} 25$ years earlier than the average age at diagnosis in the general population, ${ }^{11}$ with sporadic case reports among paediatric patients. ${ }^{14-21}$ Usually thought to be a complication diagnosed in adulthood, it is important to remember that although scarce, RCC may appear in a paediatric setting.

The diagnosis of RCC using only imaging techniques is difficult, as it is hard to differentiate RCC from AMLs that lack a prominent lipomatous component. ${ }^{11}$ Thus, frequently, biopsy and histological diagnosis are necessary.

An unusual characteristic of RCC in TSC is its histological heterogeneity. Clear-cell, papillary and chromophobe carcinoma subtypes, as well as oncocytomas, have all been reported in patients with TSC. ${ }^{14}{ }^{17}$ In this case report, bilateral renal masses were found, one corresponding to RCC clear-cell type, the most frequent histological type of RCC in TSC ${ }^{14}{ }^{15}$ and the other to a chromophobe RCC, with EMA-positive antibodies. The latter presented some atypical features, as only a few reactive cells to cytokeratin 7 antibodies and occasional cells reactive to HMB-45 were found. AMLs are known to exhibit immunoreactivity for melanocytic markers, namely HMB-45 and melanin A antibodies. ${ }^{8}$ Although HMB-45 positivity, albeit scarce, in this patients lesion suggests that his tumour might be related to an AML,${ }^{14}$ it also presented with other immunohistochemical features more suggestive of chromophobe RCC (EMA and CK7 antibodies). ${ }^{22}$ Malignant transformation of AMLs has, nevertheless, been reported and seems to have a poor prognosis. ${ }^{18} 23$

Regarding treatment, nephrectomy must be undertaken with caution in patients with TSC, as the remaining kidney is prone to develop additional masses. ${ }^{5}$ Outcomes of these patients vary, as these tumours frequently metastasise. ${ }^{14}$

This case report illustrates the importance of a close surveillance of patients with TSC, in particular of renal manifestations of disease, since these occur in a large number of patients and can become malignant over time. Accurate and timely diagnosis, as well as appropriate therapy, is crucial for a good outcome.

\section{Learning points}

- Renal involvement in tuberous sclerosis complex is common and increases with age.

- Renal angiomyolipomas can grow substantially and can cause pain or kidney failure.

- Renal malignancy is rare before adulthood but can occur.

- Close control of disease progression, with ultrasound screening of the kidneys every 1-3 years, will lead to an early diagnosis and may help to prevent further renal damage.

Contributors ATG developed the idea for the article, collected clinical data, performed the literature search and wrote the article. $A B$ carried out the literature research, helped to collect clinical data and in writing the article. CC was involved in critical revision of the manuscript. CG managed the patient, was involved in critical revision of manuscript. All the authors approved the final version.

Competing interests None. 
Patient consent Obtained.

Provenance and peer review Not commissioned; externally peer reviewed.

\section{REFERENCES}

1 Osborne JP, Fryer A, Webb D. Epidemiology of tuberous sclerosis. Ann N Y Acad Sci 1991;615:125-7.

2 Crino PB, Nathanson KL, Henske EP. The tuberous sclerosis complex. N Engl J Med 2006;355:1345-56

3 van Slegtenhorst $M$, de Hoogt $R$, Hermans $C$, et al. Identification of the tuberous sclerosis gene TSC1 on chromosome 9q34. Science 1997;277:805-8.

4 Kandt RS, Haines JL, Smith M, et al. Linkage of an important gene locus for tuberous sclerosis to a chromosome 16 marker for polycystic kidney disease. Nat Genet 1992;2:37-41.

5 Rakowski SK, Winterkorn EB, Paul E, et al. Renal manifestations of tuberous sclerosis complex: incidence, prognosis, and predictive factors. Kidney Int 2006;70:1777-82.

6 Dabora SL, Jozwiak S, Franz DN, et al. Mutational analysis in a cohort of 224 tuberous sclerosis patients indicates increased severity of TSC2, compared with TSC1, disease in multiple organs. Am J Hum Genet 2001;68:64-80.

7 Roach ES, Gomez MR, Northrup H. Tuberous sclerosis complex consensus conference: revised clinical diagnostic criteria. J Child Neurol 1998;13:624-8.

8 Dixon BP, Hulbert JC, Bissler JJ. Tuberous sclerosis complex renal disease. Nephron Exp Nephrol 2011;118:e15-20.

9 Borkowska J, Schwartz RA, Kotulska K, et al. Tuberous sclerosis complex: tumors and tumorigenesis. Int J Dermatol 2011;50:13-20.

10 O'Callaghan FJ, Noakes MJ, Martyn CN, et al. An epidemiological study of renal pathology in tuberous sclerosis complex. BJU Int 2004;94:853-7.

11 Henske EP. Tuberous sclerosis and the kidney: from mesenchyme to epithelium, and beyond. Pediatr Nephrol 2005;20:854-7.
12 Curatolo P, Bombardieri R, Jozwiak S. Tuberous sclerosis. Lancet 2008:372:657-68

13 Cook JA, Oliver K, Mueller RF, et al. A cross sectional study of renal involvement in tuberous sclerosis. J Med Genet 1996;33:480-4.

14 Bjornsson J, Short MP, Kwiatkowski DJ, et al. Tuberous sclerosis-associated renal cell carcinoma. Clinical, pathological, and genetic features. Am J Pathol 1996;149:1201-8.

15 Washecka R, Hanna M. Malignant renal tumors in tuberous sclerosis. Urology 1991;37:340-3.

16 Behnes $\mathrm{CL}$, Schutze $\mathrm{G}$, Engelke $\mathrm{C}$, et al. 13-year-old tuberous sclerosis patient with renal cell carcinoma associated with multiple renal angiomyolipomas developing multifocal micronodular pneumocyte hyperplasia. BMC Clin Pathol 2013:13:4

17 Robertson FM, Cendron M, Klauber GT, et al. Renal cell carcinoma in association with tuberous sclerosis in children. J Pediatr Surg 1996:31:729-30.

18 Al-Saleem T, Wessner LL, Scheithauer BW, et al. Malignant tumors of the kidney, brain, and soft tissues in children and young adults with the tuberous sclerosis complex. Cancer 1998;83:2208-16.

19 Breysem L, Nijs E, Proesmans W, et al. Tuberous sclerosis with cystic renal disease and multifocal renal cell carcinoma in a baby girl. Pediatr Radiol 2002;32: 677-80.

20 Lendvay TS, Broecker B, Smith EA. Renal cell carcinoma in a 2-year-old child with tuberous sclerosis. J Urol 2002;168:1131-2.

21 Kubo M, Iwashita $\mathrm{K}$, Oyachi $\mathrm{N}$, et al. Two different types of infantile renal cell carcinomas associated with tuberous sclerosis. J Pediatr Surg 2011;46:E37-41.

22 Vera-Badillo FE, Conde E, Duran I. Chromophobe renal cell carcinoma: a review of an uncommon entity. Int J Urol 2012;19:894-900.

23 Pea M, Bonetti F, Martignoni G, et al. Apparent renal cell carcinomas in tuberous sclerosis are heterogeneous: the identification of malignant epithelioid angiomyolipoma. Am J Surg Pathol 1998;22:180-7.

Copyright 2013 BMJ Publishing Group. All rights reserved. For permission to reuse any of this content visit

http://group.bmj.com/group/rights-licensing/permissions.

BMJ Case Report Fellows may re-use this article for personal use and teaching without any further permission.

Become a Fellow of BMJ Case Reports today and you can:

- Submit as many cases as you like

- Enjoy fast sympathetic peer review and rapid publication of accepted articles

- Access all the published articles

- Re-use any of the published material for personal use and teaching without further permission

For information on Institutional Fellowships contact consortiasales@bmjgroup.com

Visit casereports.bmj.com for more articles like this and to become a Fellow 